\title{
Low-Temperature KHN Active RC Filter Circuit with the Effect of Compensation of Gain Areas of Operational Amplifiers
}

\author{
D.Yu. Denisenko ${ }^{1}$, N.N. Prokopenko ${ }^{1,2}$, E.A. Zhebrun ${ }^{3}$, G.A. Svizev ${ }^{3}$ \\ ${ }^{1}$ Don State Technical University, Rostov-on-Don, d.u.denisenko@gmail.com, prokopenko@sssu.ru \\ ${ }^{2}$ Institute for Design Problems in Microelectronics of RAS, Zelenograd \\ 3JSC "NIIMA "PROGRESS", Moscow, jackjk@mail.ru, grits1989@mail.ru
}

\begin{abstract}
A new structure of the second-order lowsensitivity active RC filter (ARCF) with an extended frequency range is proposed. The ARCF circuit is implemented on three operational amplifiers (OA) and is recommended as a universal link in the construction of bandpass filters, as well as anti-aliasing low and high pass filters for operation in structures with analog-to-digital converters (ADC). It is shown that, due to the introduction of a new connection, additional difference coefficients appear in the transfer function of the ARCF under consideration, depending on the gain areas (GA) of the OA, which enables to reduce the effect of the frequency properties of the $O A$ on the realizable characteristics at low power consumption. The circuit design of a low-temperature radiation-hardened $O A$ on complementary junction field-effect transistors, designed for operation in severe conditions, is considered.
\end{abstract}

Keywords - universal active RC filter, anti-aliasing filter, band-pass filter, low-temperature operational amplifier, gain area, KHN filter circuit.

\section{INTRODUCTION}

Nowadays, analog filtering has been significantly sidelined by digital signal processing (DSP). However, with severe restrictions on energy consumption [1], many tasks of construction of sensor interfaces based only on DSP have not been solved [2,3]. In addition, input analog anti-aliasing filters (spectrum limiters), as a rule, are an integral part of various ADCs $[4,5]$ and affect their errors.

There is a significant number of the second-order filter architectures, providing the selection of a given spectrum of input signals in problems of instrument-making, communication and automation [6-16], including those implementing different principles of work $[11,15,2,17,3]$.

Currently, the theory of analog ARC filters, including for ADC conversion tasks, is developing in the direction of the application of new active elements (AE) [18-20] (differential difference operational amplifiers [21-26], various modifications of current conveyors [27-29,16] and amplifiers with current feedback [30-33]). Active research is being carried out in the field of tunable filters [1,4,3], as well as in the direction of searching for architectures that minimize the influence of the gain area of the $\mathrm{AE}$ on the main parameters of the ARCF [34].

However, there are more than 150 types of the AEs today $[2,18-20,3]$, but not all of them are available in the form of packaged microcircuits or chips. At the same time, the classic OAs, produced by large circulations by leading microelectronic firms, are the most common and cheap AE that are widely used in precision ARCFs [35,36,5,37-42]. Thus, more than 2,000 names of operational amplifiers are represented on the international market of microelectronic products. In this regard, the search for new ARCF architectures on the OA $[11,15]$ is still of interest. In many cases, such ARCFs can be successfully implemented in the basis of new active elements [18, 19, 3].

In space tool engineering, the ARCF design problem for working at low temperatures [43], when low power consumption is necessary, is quite relevant. This requires special architectural solutions [43].

The purpose of this article is to study the properties of the new circuit of the second order universal link, in which the effect of the gain area of the applied OAs, including the low-temperature ones, based on the ARCF amplitudefrequency characteristics (AFC) is reduced. This enables to extend the operating frequency range of the filter or, ceteris paribus, to reduce power consumption due to micro-power OAs.

\section{MODIFIED SECOND-ORDER ARC FILTER}

To reduce the effect of the GA of operational amplifiers on the amplitude-frequency characteristics of a second-order filter, it is promising to use the circuit shown in Fig. 1 [44], which contains three operational amplifiers (A1, A2, A3) and frequency seed passive elements resistors R1-R8 and capacitors C1, C2.

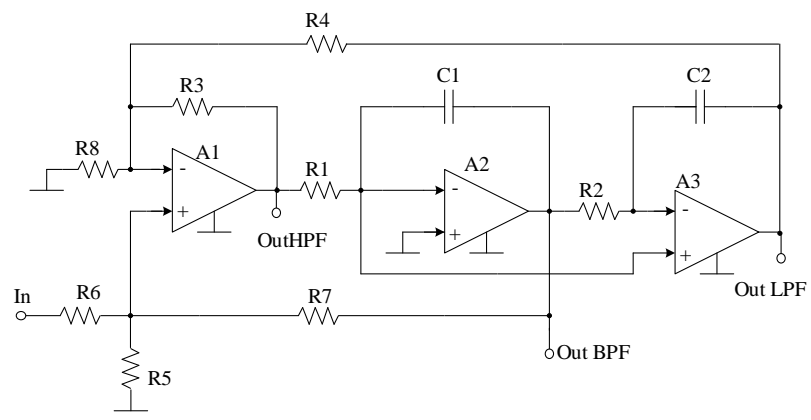

Fig. 1. Modified circuit of the universal second-order KHNfilter [44] 
Properties of the circuit of Fig. 1, on the basis of which band-pass filters (PF), low (LPF) and high (HPF) pass filters are implemented, are determined by the coefficients of its transfer function $F(p)$, which can be represented by the following formula

$$
F(p)=\frac{p b_{1}}{p^{2}+p a_{1}+a_{0}}=M \frac{p d_{p} \omega_{p}}{p^{2}+p d_{p} \omega_{p}+\omega_{p}^{2}},
$$

where $\omega_{p}$ - pole frequency, $M$ - filter gain on a pole frequency, $d_{p}$ - pole attenuation, $\boldsymbol{a}_{0}, \boldsymbol{a}_{\mathbf{1}}$ и $\boldsymbol{b}_{\mathbf{1}}$ transfer-function coefficients $F(p), p$ - Laplace variable, $Q_{p}=1 / d_{p}-$ Q-factor of the pole.

Q-factor and the transmission coefficient on the frequency of quasi-resonance [6] are relating to the most important parameters of the band-pass filters.

At low frequencies, the frequency properties of operational amplifiers have almost no effect on the amplitude frequency characteristics implemented by the filter circuit, so the basic circuit parameters - the gain factor, frequency and pole attenuation are determined by the parameters of the passive $\mathrm{R}$ and $\mathrm{C}$ elements. With an increase in the frequency range of the circuit operation, the amplification of the operational amplifiers decreases, which leads to deviation of the main parameters of the circuit from their calculated values, as they become dependent on the frequency characteristics of the OA. Thus, at higher frequencies, the transfer function coefficients (1) become dependent not only on the parameters of the passive elements, but also on the gain areas of the operational amplifiers - $G B$.

Analysis of various active RC filter circuits shows that the frequency properties of these circuits are determined not only by the parameters of the passive elements and gain areas $G B$, but also by the circuit topology, i.e. by connections between elements [34]. Thus, only due to the structural optimization of the scheme, i.e. without the inclusion of additional elements, it is possible to achieve the expansion of the frequency range of its operation.

To find the parameters of the transfer function of the proposed scheme of Fig. 1 [44] we use the signal graph method [45]. To do this, we denote the nodes in the circuit of Fig. 2a and compose its signal graph (Fig. 2b).

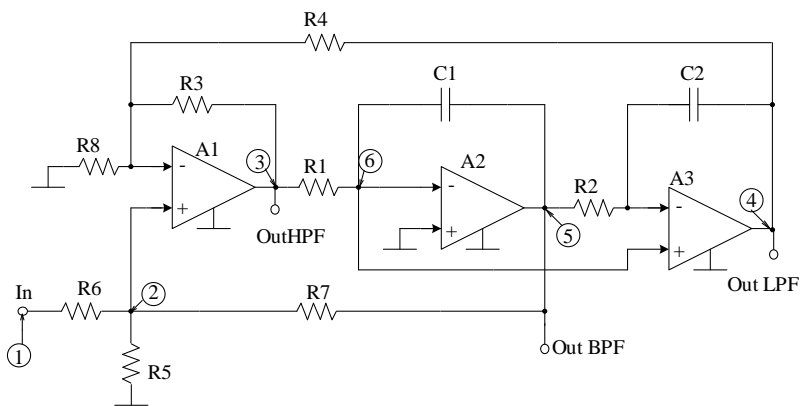

(a)

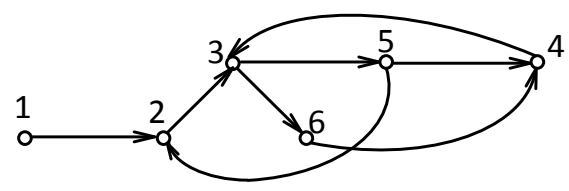

(b)

Fig. 2. The universal ARCF (a) and its signal graph (b)

Let's find the transfer function of the circuit in Fig. 2a from input 1 to output 5, which corresponds to the bandpass filter. Moreover, it can be shown that the transmission of the branches in Fig. $2 b$ is defined by the following formulas:

$$
\begin{aligned}
& \gamma_{12}=\beta_{0}=\frac{R_{5} \| R_{7}}{R_{6}+R_{5} \| R_{7}} ; \gamma_{52}=\beta_{1}=\frac{R_{6} \| R_{5}}{R_{7}+R_{5} \| R_{6}} ; \\
& \gamma_{23}(p)=\frac{1+k_{1}+k_{2}}{\frac{p}{G B_{1}}\left(1+k_{1}+k_{2}\right)+1} ; \\
& \gamma_{35}(p)=\frac{-\frac{1}{p \tau_{1}}}{\frac{p}{G B_{2}}\left(1+\frac{1}{p \tau_{1}}\right)+1} ; \\
& \gamma_{36}(p)=\frac{\frac{p}{G B_{2}}}{\frac{p}{G B_{2}}\left(1+\frac{1}{p \tau_{1}}\right)+1} ; \\
& \gamma_{54}(p)=\frac{-\frac{1}{p \tau_{2}}}{\frac{p}{G B_{3}}\left(1+\frac{1}{p \tau_{2}}\right)+1} ; \\
& \gamma_{64}(p)=\frac{1+p \tau_{2}}{\frac{p}{G B_{3}}\left(p \tau_{2}+1\right)+p \tau_{2}} \text {; } \\
& \gamma_{43}(p)=\frac{-k_{2}}{\frac{p}{G B_{1}}\left(1+k_{1}+k_{2}\right)+1} \text {; } \\
& \text { where } \quad k_{1}=\frac{R_{3}}{R_{8}} ; \quad k_{2}=\frac{R_{3}}{R_{4}} ; \quad \tau_{1}=R_{1} C_{1} \text {; } \\
& \tau_{2}=R_{2} C_{2} \text {. }
\end{aligned}
$$

As a result, the transmission from the input of the band-pass filter to its output OutBF, can be found using Mason's gain formula 


$$
F_{15}(s)=\frac{\gamma_{12} \gamma_{23} \gamma_{35}}{1-\gamma_{23} \gamma_{35} \gamma_{52}-\gamma_{35} \gamma_{54} \gamma_{43}-\gamma_{43} \gamma_{36} \gamma_{64}}
$$

Substituting the transmissions of branches in the last formula and comparing the resulting expression with formula (1), we find the idealized parameters of the considered circuit in Fig. 2a:

- transmission coefficient on the pole frequency

$$
M=\frac{R_{7}}{R_{6}},
$$

- $\quad$ pole frequency

$$
\omega_{p}=\sqrt{\frac{k_{2}}{\tau_{1} \tau_{2}}},
$$

- $\quad$ pole attenuation

$$
d_{p}=\left(1+k_{1}+k_{2}\right) \frac{\beta_{1}}{\sqrt{k_{2}}} \sqrt{\frac{\tau_{2}}{\tau_{1}}} .
$$

The gain factor of the nonideal OA depends on the frequency. In many cases, the corrected OA can be represented by the first-order transfer function.

$$
F_{O A}(p)=\mu \frac{\omega_{o a}}{p+\omega_{o a}}=\frac{G B}{p+\omega_{o a}},
$$

where $\boldsymbol{\mu}$ - gain factor of the OA at the direct current (on zero frequency), $\omega_{\text {oa }}$ - boundary frequency of the OA (the frequency on which $\mu$ decreases to the level of $0.707 \mu), G B$ - gain area of the OA.

Taking into account the limited band-pass of the OA (5) in Fig. 2 the scheme analysis showed that the coefficients of the denominator of its transfer function (1) are defined by the following expressions:

$$
\begin{gathered}
a_{1}=\frac{\frac{\beta_{1}\left(1+k_{1}+k_{2}\right)}{\tau_{1}}+\frac{\beta_{1}\left(1+k_{1}+k_{2}\right)}{G B_{3} \tau_{1} \tau_{2}}}{1+\frac{1}{G B_{2} \tau_{1}}+\frac{1}{G B_{2} \tau_{2}}+\frac{k_{2}}{G B_{1} \tau_{1}}+\frac{\beta_{1}\left(1+k_{1}+k_{2}\right)}{G B_{3} \tau_{1}}} \\
-\frac{\omega_{p}^{2}\left(\frac{1}{G B_{3}}+\frac{1}{G B_{2}}+\frac{1+k_{1}+k_{2}}{G B_{1}}\right)+\frac{k_{2}}{G B_{2} \tau_{1} \tau_{2}}}{1+\frac{1}{G B_{2} \tau_{1}}+\frac{1}{G B_{2} \tau_{2}}+\frac{k_{2}}{G B_{1} \tau_{1}}+\frac{\beta_{1}\left(1+k_{1}+k_{2}\right)}{G B_{3} \tau_{1}}},
\end{gathered}
$$

$$
a_{0}=\frac{\frac{k_{2}}{\tau_{1} \tau_{2}}}{1+\frac{1}{G B_{2} \tau_{1}}+\frac{1}{G B_{2} \tau_{2}}+\frac{k_{2}}{G B_{1} \tau_{1}}+\frac{\beta_{1}\left(1+k_{1}+k_{2}\right)}{G B_{3} \tau_{1}}} .
$$

where $G B_{1}, G B_{2}, G B_{3}$ - gain areas of OAs A1, A2 and A3 correspondingly.

Let's carry out a similar analysis of the widely used circuit of Fig. 3a, which is known as a universal KHN filter $[10,25]$.

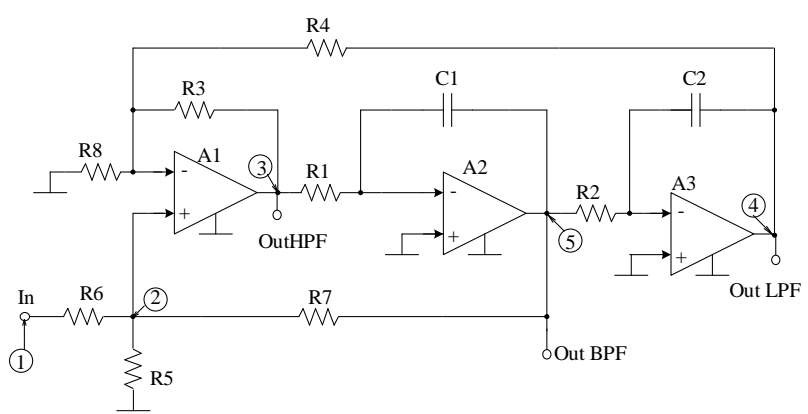

(a)

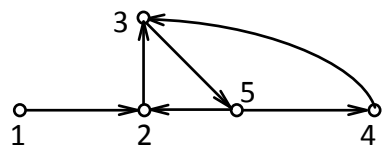

(b)

Fig. 3. Circuit of the classic KHN filter (a) and its graph (b)

For the circuit of Fig. 3a, the transfer function coefficients, similar to formulas (6) - (7), are determined by the following equations:

$$
\begin{gathered}
a_{1}=\frac{\frac{\beta_{1}\left(1+k_{1}+k_{2}\right)}{\tau_{1}}+\frac{\beta_{1}\left(1+k_{1}+k_{2}\right)}{G B_{3} \tau_{1} \tau_{2}}}{1+\frac{1}{G B_{2} \tau_{1}}+\frac{1}{G B_{2} \tau_{2}}+\frac{\beta_{1}\left(1+k_{1}+k_{2}\right)}{G B_{3} \tau_{1}}}- \\
-\frac{\omega_{p}^{2}\left(\frac{1}{G B_{3}}+\frac{1}{G B_{2}}+\frac{1+k_{1}+k_{2}}{G B_{1}}\right)}{1+\frac{1}{G B_{2} \tau_{1}}+\frac{1}{G B_{2} \tau_{2}}+\frac{\beta_{1}\left(1+k_{1}+k_{2}\right)}{G B_{3} \tau_{1}}},
\end{gathered}
$$

$$
a_{0}=\frac{\frac{k_{2}}{\tau_{1} \tau_{2}}}{1+\frac{1}{G B_{2} \tau_{1}}+\frac{1}{G B_{2} \tau_{2}}+\frac{\beta_{1}\left(1+k_{1}+k_{2}\right)}{G B_{3} \tau_{1}}} .
$$

It should also be noted that from formulas (6) - (9), when $G B \rightarrow \infty$, the idealized parameters of filter circuits 
(2) - (4) can be found. The same formulas are also valid for filter circuits operating on low frequencies, where the effect of the gain areas of the OA is negligible.

\section{THE CIRCUIT DESIGN OF THE OA FOR OPERATION AT LOW TEMPERATURES, INCLUDING THE CRYOGENIC ONES}

The stability of the implemented parameters of active RC-filters depends not only on the temperature coefficients of resistances and capacitors, but also on the properties of the active elements, which must keep their parameters in a wide temperature range. In this regard, when designing ARC filter circuits, it is advisable to use the OA, the circuit design of which was developed taking into account their work up to cryogenic temperatures [43].

Low noise cryogenic operational amplifiers can be implemented on complementary junction field-effect transistors (JFET). The proposed scheme of such OA (Fig. 4) contains non-traditional input stage and a buffer amplifier based on the JFET properties of the active elements of OAO "Integral” (Minsk).

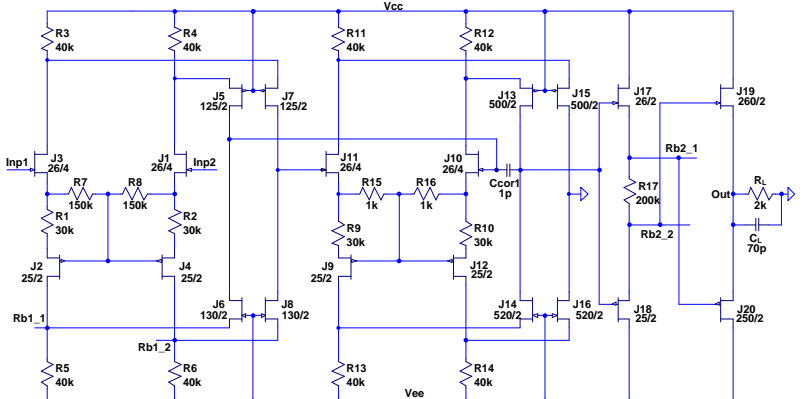

Fig. 4. The simplified electric circuit of cryogenic $\mathrm{OA}$ of JFET_OAmp3

The results of computer simulation of the OA circuit of Fig. 4 at the temperature $\mathrm{T}=-197{ }^{\circ} \mathrm{C}$ are presented in Fig. 5 .

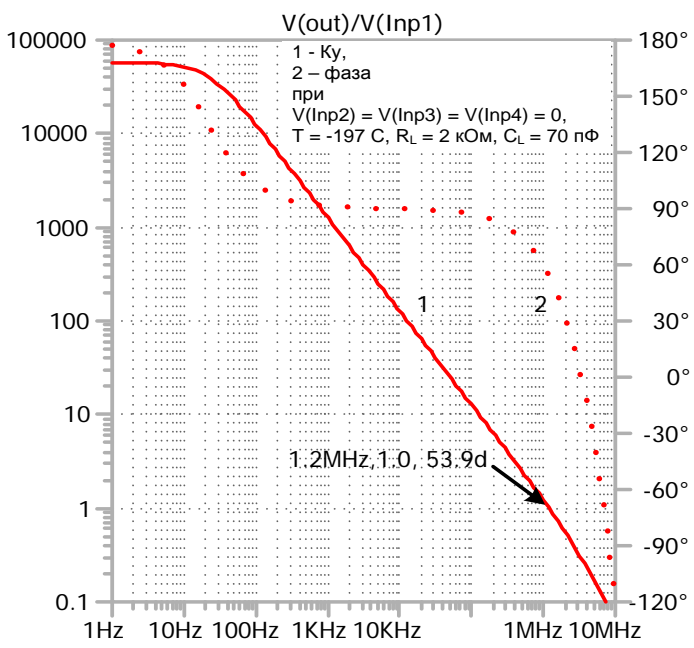

Fig. 5. The amplitude-frequency and phase-frequency characteristics of the DDOA OAmp3 at $\mathrm{T}=-197^{\circ} \mathrm{C}$

\section{THE RESULTS OF COMPUTER SIMULATION OF THE BAND-PASS FILTER}

Fig. 6 shows the simulation results of the new filter circuit of Fig. 1 for PF output and the well-known universal KHN filter of Fig. 3a on different frequencies of quasiresonance in the range from 10 to $100 \mathrm{kHz}$.

From the analysis of graphs in Fig. 6 it follows that with the same OAs, including Fig. 4, in the compared circuits, the frequency range of the new scheme is expanded by approximately one and a half times. In this case, the relative winning on the frequency range will be the higher, the smaller the GA of the applied OA.

Similar results can be obtained for the low and high pass filter outputs. However, deriving the basic equations for these ARCF versions we should take into account the effect of $G B 1, G B 2, G B 3$ on the coefficient $b_{1}$ in formula (1).

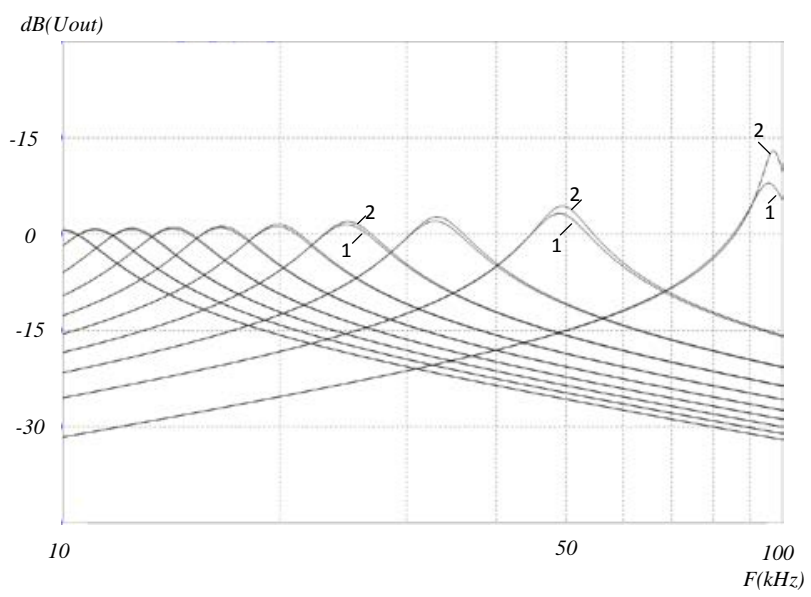

Fig. 6. The amplitude frequency characteristic of the new circuit (1) and the KHN-filter circuit (2)

\section{CONCLUSION}

The proposed circuit of the universal filter of the second order reduces the effect of the gain area $G A$ of the operational amplifiers on the amplitude frequency characteristics. Depending on Q factor implemented and the frequency properties of the $\mathrm{OA}$, the frequency range of the considered band-pass filter is approximately 1.5 times larger than in the widely used classical KHN filter. Moreover, this effect is achieved without any additional elements - due to the introduction of a single new connection between the elements of the well-known KHN filter (connection of the non-inverting input of OA A2 with the non-inverting input of OA A3).

In the studied filter circuit, micropower OAs can be used, which enables us to recommend it for the use in lowtemperature analog-digital interfaces of automation and communication systems. The application of the proposed circuit design solution is also promising when implementing the ARC filters on new classes of active elements, including the differential difference operational amplifiers and the cryogenic ones. 


\section{SUPPORT}

The research has been carried out at the expense of the Grant of the Russian Science Foundation (project No. 18-79-10109).

\section{REFERENCES}

[1] Spiridon S., Op't Eynde F. Low power CMOS fully differential programmable low pass filter //Proceedings of the 10th IEEE International Conference on Optimization Of Electrical And Electronic Equipment. 2006. P. 21-25.

[2] Kuntman H. H., Uygur A. New possibilities and trends in circuit design for analog signal processing // 2012 International Conference on Applied Electronics, Pilsen, 2012. P. 1-9.

[3] Sánchez-Sinencio E. Analog filter design: Current design techniques and trends //2017 IEEE Custom Integrated Circuits Conference (CICC), Austin, TX, 2017. P. 1-76. DOI: 10.1109/CICC.2017.7993716

[4] Boiano C., Guazzoni P., Zetta L., Guazzoni C., Pagano A.A 16-channel programmable antialiasing amplifier // 2010 IEEE Nuclear Science Symposium Conference Record (NSS/MIC), Knoxville, TN, 2010. P. 1389-1391. DOI: 10.1109/NSSMIC.2010.5873999

[5] Denisenko D.Yu., Ivanov Yu.I., Prokopenko N.N. Vybor parametrov analogovykh ogranichiteley spektra dlya tsifrovykh sistem obrabotki signalov s uchetom dopuskov i temperaturnoy nestabil'nosti passivnykh komponentov (Selection of parameters for analogue spectrum limiters for digital signal processing systems taking into account tolerances and temperature instability of passive components) // Radiotekhnika. 2017. № 1. S.148-153. (in Russian)

[6] Huelsman L.P. and Allen P.E., Introduction to the Theory and Design of Active Filters. McGraw-Hill: New York, 1980. 429 p.

[7] Bukashkin S.A., Vlasov V.P., Zmiy B.F., Kalyakin A.I., Krutchinskiy S.G., Kuflevskiy E.I., Lanne A.A., Maslennikov V.V., Men'shikov A.M., Mikhalev P.G., Petrakov V.A., Sirotkin A.P., Slavskiy G.N., Styts'ko V.P. Spravochnik po raschetu i proektirovaniyu ARC-skhem (Guide to the calculation and design of ARC-schemes). M.: Radio i svyaz', 1984. 368 s. (in Russian)

[8] Moschytz G.S., Horn P. Active filter design handbook. John Wiley \& Sons, Inc. New York, NY, USA, 1981. 316 p.

[9] Kapustyan V.I. Aktivnye RC-fil'try vysokogo poryadka (Active RC filters are of high order). M.: Radio i svyaz', 1985. 248 s. (in Russian)

[10] Lam H.Y.-F. Analog and Digital Filters: Design and Realization, Prentice-Hall, Inc, Englewood Cliffs, New Jersey, 1979. $592 \mathrm{p}$.

[11] Ananda Mohan P.V. VLSI analog filters: active RC, OTA-C, and SC. New York: Birkhäuser: Springer Science+Business Media, 2013. 620 p. DOI: 10.1007/9780-8176-8358-0

[12] Schubert T. F., Kim E.M. Fundamentals of Electronics, Book 3. Active Filters and Amplifier Frequency Response. Morgan \& Claypool Publishers, 2016. 292 p. DOI: 10.2200/S00712ED1V03Y201603DCS049

[13] Dimopoulos H.G. Analog Electronic Filters: Theory, Design and Synthesis. Springer, Netherlands, 2012. 498 pp. DOI: 10.1007/978-94-007-2190-6

[14] Ivanov Yu.I. Universal'nyy aktivnyy RC-fil'tr (Universal active RC filter). Pat. № 2149499, opubl. 20.05.2000, Byul. № 14. (in Russian)

[15] Fortunato M. A new filter topology for analog high-pass filters //TI Analog Applications Journal. 2008. P. 18-24.
[16] Korotkov A.S., Tutyshkin A.A. Tokovye konveyery: razvitie, skhemotekhnika, primenenie (Current conveyors: development, circuitry, application) // Zarubezhnaya radioelektronika. 2002. № 11. C. 64-78. (in Russian)

[17] Korotkov A.S. Integral'nye analogovye fil'try (Integral analog filters) // Izvestiya TRTU. Izbiratel'nyesistemy s obratnoy svyaz'yu. Vyp. № 2. Taganrog, 1995. S. 47-50. (in Russian)

[18] Biolek D., Senani R., Biolkova V., Kolka Z. Active elements for analog signal processing: classification, review, and new proposals // Radioengineering, 2008. V. 17, № 4, P. 15-32.

[19] Senani R., Bhaskar D.R., Singh V.K., Sharma R.K. Sinusoidal Oscillators and Waveform Generators using Modern Electronic Circuit Building Blocks // Springer International Publishing, Switzerland, January 2016. 622 p. DOI: 10.1007/978-3-319-23712-1

[20] Kumngern M. DDTA and DDCCTA: New active elements for analog signal processing // 2012 IEEE International Conference on Electronics Design, Systems and Applications (ICEDSA), Kuala Lumpur, 2012. P. 141-145. DOI: 10.1109/ICEDSA.2012.6507784

[21] Stornelli V., Pantoli L., Leuzzi G., Ferri G. Fully differential DDA-based fifth and seventh order Bessel low pass filters and buffers for DCR radio systems //Analog Integrated Circuits and Signal Processing. 2013. V. 75 № 2. P. 305-310. DOI: https://doi.org/10.1007/s10470-0130051-9

[22] Soltan A., Soliman A. M. A CMOS differential difference operational mirrored amplifier // AEU-International Journal of Electronics and Communications. 2009. V. 63. № 9. P. 793-800. DOI: https://doi.org/10.1016/j.aeue.2008.06.004

[23] Sackinger E., Guggenbuhl W. A versatile building block: the CMOS differential difference amplifier // IEEE Journal of Solid-State Circuits, Apr 1987. V. 22. № 2. P. 287-294. DOI: 10.1109/JSSC.1987.1052715

[24] Sackinger E., Guggenbuhl W. A versatile building block: the CMOS differential difference amplifier // IEEE Journal of Solid-State Circuits, Apr 1987. V. 22. № 2. P. 287-294. DOI: 10.1109/JSSC.1987.1052715

[25] Yamacli S., Ozcan S., Kuntman H. Resistorless KHN biquad using an DDA (difference diffference amplifier) and two CCCIIs (controlled current conveyor) // Proceedings of the 2005 European Conference on Circuit Theory and Design. V. 1. P. I/181-I/184 DOI: 10.1109/ECCTD.2005.1522940

[26] Yesil A., Kacar F., Minaei S. New differential difference stage and Its application to band-pass filter at $10.7 \mathrm{MHz}$ with high quality factor // AEU - International Journal of Electronics and Communications, September 2017. V. 79. P. 74-82. DOI: http://dx.doi.org/10.1016/j.aeue.2017.05.022

[27] Senani R., Bhaskar D.R., Singh A.K. Current Conveyors: Variants, Applications and Hardware Implementations // Springer International Publishing, Switzerland, 2015. 560 p. DOI: 10.1007/978-3-319-08684-2

[28] Ghallab Y. H., Badawy W., Kaler K. V. I. S., Abou El-Ela M., El-Said M. H. A new second-order active universal filter with single input and three outputs using operational floating current conveyor // The 14th International Conference on Microelectronics, 2002. P. 42-45. DOI: 10.1109/ICM02.2002 .1161492

[29] Ghallab Y. H., Abou El-Ela M., Elsaid M. A novel universal voltage-mode filter with three inputs and single output using only two operational floating current conveyor // IEEE 12th International Conference on Microelectronics (ICM), Tehran, 2000. P. 95-98. DOI: 10.1109/ICM.2000.916422

[30] Horng J.-W. New configuration for realizing universal voltage-mode filter using two current feedback amplifiers // 
IEEE Transactions on Instrumentation and Measurement, Oct 2000. V. 49. № 5. P. 1043-1045. DOI: $10.1109 / 19.872927$

[31] Liu S.I. Universal filter using two current-feedback amplifiers // J. Electronics Letters, 13 Apr 1995. V. 31. № 8. P. 629-630. DOI: 10.1049/el:19950425

[32] Liu S.-I., Wu D.-Sh. New current-feedback amplifier-based universal biquadratic filter // IEEE J. Transactions on Instrumentation and Measurement, Aug 1995. V. 44. № 4. P. 915-917. DOI: 10.1109/19.392891

[33] Liu S.-I. High input impedance filters with low component spread using current-feedback amplifiers // J. Electronics Letters, 22 Jun 1995. V. 31. № 13. P. 1042-1043. DOI: 10.1049/el:19950725

[34] Denisenko D.Yu., Ivanov Yu.Iv., Prokopenko N.N. Topological Features of the Active RC-Filter Schemes with the Extended Frequency Operating Range // 2018 Moscow Workshop on Electronic and Networking Technologies (MWENT). Proceedings. National Research University Higher School of Economics, Moscow, Russia, March 1416, 2018. P. 1-6.

[35] Denisenko D.Yu., Grishko I.K, Ivanov Yu.I. Sistema avtomaticheskoy nastroyki analogovykh aktivnykh RCfil'trov (System for automatic adjustment of analog active RC filters) // Informatsionnye tekhnologii, sistemnyy analiz i upravlenie. ITSAU-2016; Sb. trudov KhIV Vserossiyskoy nauchnoy konferentsii molodykh uchenykh, aspirantov i studentov, 16-19 noyabrya 2016 g. Taganrog: Izd-vo YuFU, 2016. T. 1. S. 120-122. (in Russian)

[36] Makarova Yu., Bugrov V. Poiskovoe proektirovanie aktivnykh antialiasingovykh fil'trov (Search design of active antialiasing filters) // Sovremennaya elektronika, 2017. № 1. S. 76-80. (in Russian)

[37] Kuflevskiy E.I., Gura V.D., Ivanov Yu.I., Lysenko G.V., Makarenko B.F. Opyt razrabotki pretsizionnykh aktivnykh fil'trov v gibridno-plenochnom ispolnenii (Experience in the development of precision active filters in hybrid-film design) // Tezisy doklada na X moskovskoy NTK, poev. Dnyu radio. M.: Radio i svyaz', 1984. S. 81. (in Russian)

[38] Kuflevskiy E.I., Ivanov Yu.I. Skhemotekhnika i realizatsiya mikroelektronnogo fil'tra nizhnikh chastot (Circuitry and implementation of low-pass microelectronic filter) //
Poluprovodnikovaya elektronika $\mathrm{v}$ tekhnike svyazi: sb. statey / Pod red. I.F. Nikolaevskogo. M.: Radio i svyaz', 1990. Vyp. 28. S. 63-67. (in Russian)

[39] Ivanov Yu.I. Sintez ekonomichnykh zven'yev ARC-fil'trov s uchetom ogranicheniy gibridno-plenochnoy tekhnologii (Synthesis of economical links of ARC-filters taking into account the limitations of hybrid-film technology) // Trudy 6 Vserossiyskoy NTK s mezhdunarodnym uchastiem “Aktual'nye problemy tverdotel'noy elektroniki i mikroelektroniki”, Divnomorsk, 1999. S. 68. (in Russian)

[40] Denisenko D.Yu., Denisenko M.E., Ivanov Yu.I., Finaev V.I. Analogovye i diskretno-analogovye perestraivaemye integratory (Analog and discrete analog reconfigurable integrators) // IVD. 2015. №4-1. URL: http://ivdon.ru/ru/magazine/archive/n4y2015/3388 (access date: 01.04.2018). (in Russian)

[41] Ivanov Yu.I., Nakoryakov A.V. Chastotnye svoystva nizkochuvstvitel'nykh aktivnykh RC-fil'trov vtorogo poryadka (Frequency characteristics of low-sensitivity active RC filters of the second order) // Problemy sovremennoy analogovoy mikroskhemotekhniki: cb. materialov VI Mezhdunarodnogo nauchno-prakticheskogo seminara. V 3-kh ch. Ch. 1. Funktsional'nye uzly analogovykh integral'nykh skhem i slozhnykh funktsional'nykh blokov / pod red. N.N. Prokopenko. Shakhty: Izd-vo YuRGUES, 2007. S. 149-155. (in Russian)

[42] Sallen R.P. and Key E.L. A Practical Method of Designing RC Active Filters // IRE Trans. Circuit Theory. V. CT-2. March 1955. P. 78-85. DOI: 10.1109/TCT.1955.6500159

[43] Ma D., Geng X., Dai F. F., Cressler J. D. A 6th order Butterworth SC low pass filter for cryogenic applications from $-180^{\circ} \mathrm{c}$ to $120^{\circ} \mathrm{c} / / 2009$ IEEE Aerospace conference, Big Sky, MT, 2009. P. $1-8$. DOI: 10.1109/AERO.2009.4839524

[44] Denisenko D.Yu., Prokopenko N.N. Aktivnyy RC-fil'tr (Active RC Filter). Zayavka na patent RF № 2018108897, zayav.: 14.03.18. (in Russian)

[45] Sigorskiy V.P., Petrenko A.I. Osnovy teorii elektronnykh skhem (Fundamentals of the theory of electronic circuits). Kiev.:.Vishcha shkola, 1971. 568 s. (in Russian) 